\title{
Cry Protein Profiling of Bacillus thuringiensis Isolated from Different Agro-Climate Soils of Punjab
}

\author{
Babita Mukhija ${ }^{1}$ and Veena Khanna ${ }^{2}$ \\ ${ }^{1}$ Department of Microbiology, Punjab Agricultural University, Ludhiana, Punjab, India \\ ${ }^{2}$ Department of Plant Breeding and Genetics, Punjab Agricultural University, \\ Ludhiana, Punjab, India \\ *Corresponding author
}

\section{A B S T R A C T}

\section{Keywords \\ Bacillus \\ thuringiensis, Cry protein, Molecular mass, Sporulation \\ Article Info \\ Accepted: \\ 24 February 2018 \\ Available Online: \\ 10 March 2018}

Insect pests caused the yield loss in agricultural crops and forestry plants world widely. Commercial biopesticides based on Bacillus thuringiensis $(\mathrm{Bt})$ have been used for pest management. The most important factor that makes $\mathrm{Bt}$ as commercial biopesticides is its remarkable ability to produce large quantities of larvicidal proteins (known as Cry protein or delta-endotoxin) that form crystalline inclusion bodies during sporulation. However, use of $\mathrm{Bt}$ based biopesticides is limited due to high production cost of $\mathrm{Bt}$ based biopesticides. Therefore, using alternative raw materials with the low cost is very important. differences amongst the strains of $B$. thuringiensis have been reported among 21 strains of $\mathrm{Bt}$, reported three protein banding patterns ranging from low molecular mass $(35-66 \mathrm{kDa})$, medium molecular mass (66-80 kDa) and high molecular mass only (80-116 kDa.)

\section{Introduction}

Microbial insecticides are being developed as biological control agents during the last three decades. The widely known and used bacteria as insect pathogens belong to Bacillus genus and these are $\mathrm{Bt}, B$. lentimorbus, and $B$. sphaericus. The most common biopesticides applied in many agro ecosystems are the commercial formulations of Bt (Entwistle et al., 1993). Cry1, Cry2, and Cry9 proteins show strongest toxicity to Lepidopterans (Crickmore 2000). Proteins belonging to the class Cry4 and Cry11 are specifically toxic to Dipterans. Cry3, Cry7, Cry8, Cry14, Cry18,
Cry34, and Cry35 (de Maagd et al., 2001) proteins show insecticidal activity against Coleopterans. Some Cry proteins on the other hand display toxicity to more than one insect order. Each insecticidal crystal protein is the product of a single gene. The genes synthesize these endotoxins are often located on large, transmissible plasmids.

Cry proteins are the predominant type. Two types of -endotoxin are produced by Bt strains. They are named Cry and Cyt proteins. Cry and Cyt proteins differ structurally. The most important feature of these proteins is their pathogenicity to insects and each crystal 
protein has its distinct host range. The crystal proteins are encoded by cry genes. The accumulation of Cry protein in a mother cell can make up 20-30\% of the dry weight of the sporulated cells (Agaisse and Lereclus, 1995). Each crystal protein has its own insecticidal spectrum. Therefore, Cry proteins have been classified on the basis of their host specificity and their amino acid compositions (Jensen et al., 2003).

Sodium dodecyle sulphate polyacrylamide gel electrophoresis (SDS-PAGE) analysis is generally used to compare protein profiles of B. thuringiensis isolates. For example, Bel et al., (1997) used SDS-PAGE analysis in order to determine the differences among the $B$. thuringiensis isolates collected from different olive tree environments. Hofte and Whiteley (1989) reported that the size of Cry 1 and Cry 2 proteins of $B$. thuringiensis subsp. kurstaki were different, Cry 1 type of protein was between 130-150 kDa; Cry 2 type protein was at $70 \mathrm{kDa}$; Cry 3 type protein was at $75 \mathrm{kDa}$ and Cry 9 type protein was at 130-140 kDa.

Over synthetic pesticides, the advantages of this organism include lack of polluting residues, high specificity to target insects, safety to non-target organisms such as mammalians, birds, amphibians and reptiles as well as its relatively low costs of development and registration (Flexner and Belnavis 1999). In spite of these economical benefits, the use of Bt-based biopesticides is much less than synthetic chemicals.

\section{Materials and Methods}

\section{Collection of soil sample and isolation of Bacillus thuringiensis}

Isolation of $\mathrm{Bt}$ strains was carried out from soil samples collected from different locations of the Punjab state following the method of Travers et al., (1987). About $5 \mathrm{gm}$ of soil sample was added to $100 \mathrm{ml}$ of Luria broth buffered with $0.25 \mathrm{M}$ sodium acetate. The mixture was shaken for $4 \mathrm{~h}$ at $250 \mathrm{rpm}$ at $30^{\circ}$ C. A sample was then taken and heat treated at $80^{\circ} \mathrm{C}$ for $3 \mathrm{~min}$. About $0.2 \mathrm{ml}$ suspension was plated on Luria agar and incubated over night at $30 \pm 2{ }^{\circ} \mathrm{C}$. Random sample of colonies were then picked on $\mathrm{T}_{3}$ medium and allowed to sporulate at $30 \pm 2{ }^{\circ} \mathrm{C}$. Cultures were the checked for the presence of crystals (Ohba and Aizawa, 1986) using a Phase Contrast Microscope (Nikon, Trinocular).

\section{Biochemical characterization of bacteria}

The isolates of $B t$ from soil samples were categorized on the basis of these biochemical tests viz. carbohydrate utilization, Voges Proskauer test, Starch hydrolysis, casein hydrolysis, methyl-red test, catalase positive test, citrate and nitrate reduction test.

\section{Confirmation of crystal protein presence}

Cultures of approximately five days were analyzed by light microscopy (Nikon E-200 Eclipse) by staining with Coomassie blue $(0,25 \%(\mathrm{w} / \mathrm{v})$ in $60 \%$ ethanol (v/v) and $7 \%$ of acetic acid $(\mathrm{v} / \mathrm{v})$, for the confirmation of crystal structure. The smear was prepared on glass slide and heat fixed. Later it was stained and washed in running tap water. The stained cultures were observed through light microscope for the presence of spore formation.

\section{Polyacrylamide gel electrophoresis}

Crystal-spore preparations were analyzed for the presence of the $\delta$-endotoxins in $10 \%$ SDSPAGE gels. A single colony was inoculated into Luria broth and allowed to grow at $30 \pm$ $2^{\circ} \mathrm{C}, 200 \mathrm{rpm}$ for $48-72 \mathrm{~h}$. Once the cells sporulated, $1.5 \mathrm{ml}$ of roth was harvested by centrifugation and washed once with distilled water. The pellet was suspended in T.E. buffer 
(pH 8.0). About $45 \mu 1$ sample was mixed with SSB $\quad(1 \% \quad \mathrm{w} / \mathrm{v} \quad \mathrm{SDS}, \quad 0.1 \quad \% \quad \mathrm{v} / \mathrm{v} \quad \beta-$ mercaptoethanol, $10 \% \mathrm{v} / \mathrm{v}$ glycerol and bromophenol blue). They were heated in a boiling water bath for 5 mins before electrophoresis. About $50 \mu \mathrm{l}$ of the sample was loaded into each well with a stringe and gel was run overnight at 40v (Vertical slab gel electrophoresis, Atta, Japan).

The molecular weight of the Cry proteins was determined by comparing with protein markers of known molecular weight (BR Biochem 161-0304).

\section{Results and Discussion}

A total of 68 soil samples were collected from 19 different regions of Punjab. Samples were collected by scraping off the soil surface with sterile spatula and about $10 \mathrm{~g}$ of soil were obtained at a depth of $2-5 \mathrm{~cm}$. All samples were kept aseptically in sterile plastic bags and stored at $4^{\circ} \mathrm{C}$. One hundred and forty Bacillus thuringiensis were iaolated from these soil samples according to sodium acetate selection method.

$B t$ colonies which are usually as creamcolored and have the appearance of fried egg on plate were sub cultured on Bt specific $\mathrm{T} 3$ medium (per liter, Tryptone-3g, Tryptose-2g, Yeast extract-1.5g, Sodium monophosphate$6.9 \mathrm{~g}$, Disodium hydrogen phosphate- $8.9 \mathrm{~g}$, $\mathrm{MnCl} 2-0.005 \mathrm{~g}$, and $\mathrm{pH}$ 6.8) and incubated at $30^{\circ} \mathrm{C}$ for $24 \mathrm{hrs}$. Then the culture was stored at $4^{\circ} \mathrm{C}$ for further work.

Various biochemical tests exhibited abundant growth of the isolates on nutrient agar $(\mathrm{pH} 7$. 5), producing acid from glucose but lactose, arabinose, rhamnose, mannitol, sorbitol negative. Starch and casein hydrolysis and gelatin liquification was also observed in all the cultures. Catalase production was also observed. The cultures also utilized citrate and reduced nitrate to nitrite. Based on their biochemical characterization, they were identified to be strains of Bacillus thuringiensis (Table 1). Some of these tests have been used in the studies of Cinar et al., 2005 to characterize their native isolate as $B t$.

Biotypes of $B$. thuringiensis had the presence of shining crystals in the endospores, which were seen under light microscope after staining with Coomassie blue, made sure Bt strains harboring crystalline inclusions that might have potential for use as bioinsecticidal agent.

Ten per cent sodium dodecyl sulphate, Polyacrylamide gel electrophoresis was carried out with freshly sporulating cultures to determine the number and molecular mass of the 21 positive crystal polypeptides using 4AA1 as reference strain. In the present study, significant differences amongst the 21 strains of $B$. thuringiensis have been reported. $B$. thuringiensis showed existence of 115 kDa, $110 \mathrm{kDa}, 100 \mathrm{kDa}, 90 \mathrm{kDa}, 85 \mathrm{kDa}, 80$ $\mathrm{kDa}, 75 \mathrm{kDa}, 70 \mathrm{kDa}, 68 \mathrm{kDa}, 60 \mathrm{kDa}, 40$ $\mathrm{kDa}, 35 \mathrm{kDa}, 25 \mathrm{kDa}, 20 \mathrm{kDa}$ and $10 \mathrm{kDa}$. The reference strain $B$. thuringiensis subsp. morissoni LM 79 showed protein band of 25$220 \mathrm{kDa}$. These results (Plate 13) revealed that $\mathrm{Bt}$ isolates generated proteins with molecular weight of $10-115 \mathrm{kDa}$ which were almost similar to those of the reference strains. Bt 34 and $\mathrm{Bt} 35$ produced dense band of a $115 \mathrm{kDa}$ protein (consistent with the presence of a cry3 gene product); most of the isolates synthesized a protein or a group of proteins with molecular weights between 25 and $90 \mathrm{kDa}$. The presence of proteins or group of proteins with molecular weights $25-75 \mathrm{kDa}$ and 75- 115 $\mathrm{kDa}$ suggested that the isolated strains contain genes related to cry3 which are known to be active against coleoptera. However, a few isolates showed varying protein pattern. Some weak bands were also observed during toxin protein analysis (Fig. 1). 
Table.1 Cultural and biochemical characteristics of Bacillus thuringiensis isolates

\begin{tabular}{|l|}
\hline Test Character \\
\hline Gram's reaction \\
\hline Shape \\
\hline Pigment \\
\hline Pigment colour \\
\hline Starch hydrolysis \\
\hline Casein hydrolysis \\
\hline Catalase production \\
\hline Methyl red test \\
\hline Citrate utilization \\
\hline Nitrate reduction \\
\hline
\end{tabular}

\section{Bacillus isolated from Luria Agar medium}

+ve

Round, white and smooth

+ve

Creamish

$+\mathrm{ve}$

+ve

+ve

-ve

-ve

+ve

Fig.1 SDS-PAGE, protein profiling of native B. thuringiensis with reference strain. Lane 1: Protein MW Marker, 2: Bt15, 3: Bt16, 4: Bt20, 5: Bt35, 6: Bt34, 7: Bt36, 8: Bt60, 9: Bt39, 10:

Bt38, 11: Bt54, 12: 47, 13: Bt50, 14: Standard strain

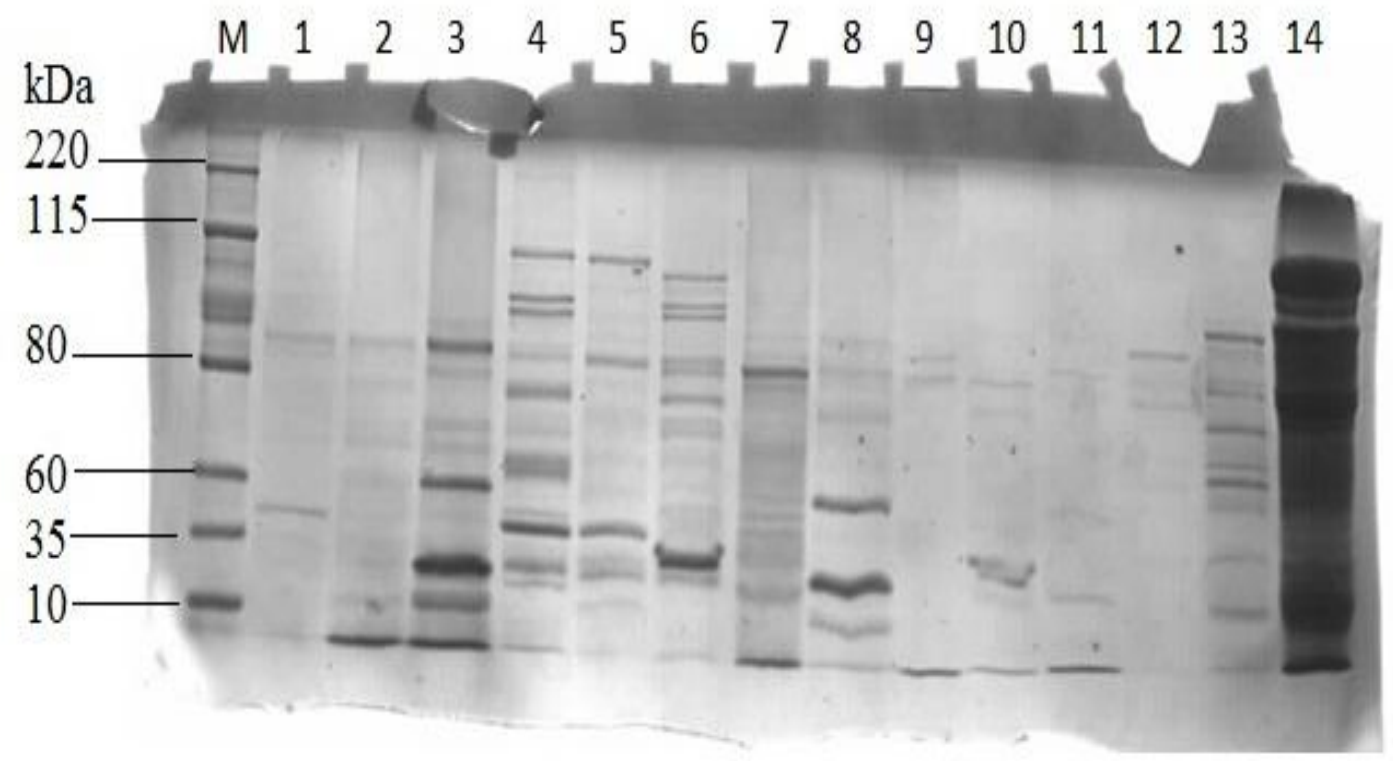

Insufficient protein concentration could be a reason for that, and therefore protein bands were not detectable with Coomassie brilliant blue staining. Ellis et al., 2002, suggested, the crystal morphology of the bacterium referring to protein Cry35Ba, $44 \mathrm{kDa}$ could be associated to toxicity against coleopteran. In another study of Silva $\mathrm{N}$ et al., 2010 reported, a protein identified by SDS-PAGE analysis showed $120 \mathrm{kDa}$ protein band which indicated a new Cry3 protein.

Comparison of the protein pattern has been reported to be useful in evaluation of the relationship between $B t$ isolates (Swiecicka and De Vos, 2003). 
Ellis et al., 2002, suggested that this crystal morphology of the bacterium referring to protein $\mathrm{Cry} 35 \mathrm{Ba}, 44 \mathrm{kDa}$ could be associated to toxicity against coleopteran. In another study of Silva $\mathrm{N}$ et al., 2010, identified protein by SDS-PAGE analysis and reported a $120 \mathrm{kDa}$ protein band for one isolate which indicated a new Cry protein. Moreover, their study highlights the relations between the genetic profiles for gene cry $35 \mathrm{Ba}$, the $44 \mathrm{kDa}$ proteins and the spherical morphology are present in all isolates effective against $S$. oryzae. Several B. thuringiensis subspecies produce a series of other toxins besides the Cry proteins (Caballero and Ferré 2001). However this was not the aim of the present work that was carried out using spore/crystal suspension in the bioassays, with the possibility of one or more Cry proteins being expressed at one time as described by Fatoretto et al., (2007).

\section{Acknowledgements}

The authors express their sincere thanks to Confederation of Indian Industry (CII), Science Engineering Research Board (SERB) and Sampuran Agriventures Pvt. Ltd., Chandigarh for the financial grant received under Prime minister's Fellowship Scheme for Doctoral research.

\section{References}

Agaisse H and Lereclus D (1995) How Does Bacillus thuringiensis produce so much insecticidal crystal protein. J Bacteriol 177: 6027-32.
Caballero P and Ferre J (2001) Bioinsecticides: Foundations and applications of Bacillus thuringiensis in the integrated control of pests. Phytoma-Spain 1: 1-320.

Crickmore N (2000) The diversity of Bacillus thuringiensis $\delta$-endotoxins in entomopathogenic bacteria: From laboratory to field application, edited by J.F. Charles, A. Delécluse, and C. Nielsen-LeRoux (Kluwer Academic, Dordrecht), pp. 65-79.

De Maagd R A, Bravo A and Crickmore N (2001) How Bacillus thuringiensis has evolved specific toxins to colonize the insect world Trends in Gen 17:193-99.

Entwistle P F, Lory J S, Baily M J and Higgs S (1993) Bacillus thuringiensis, An Environmental Biopesticide (John Wiley, New York).

Fatoretto J C, Sena J A D, Barreto M R, Lemos M V F, Boica and Júnior A L (2007) Bioassays Association for molecular characterization and selection of new isolates of Bacillus thuringiensis effective against Spodoptera frugiperda(JE Smith) (Lepidoptera: Noctuidae). Bio con 36: 737-45.

Flexner J L and Belnavis D L (1999) Microbial insecticides, in Biological and biotechnological control of Insect Pests, edited by J.E. Rechcigland N.A. Rechcigl (Lewis Publishers), pp. 35-62.

Jensen M A, Webster J A and Straus N (2003) Rapid identification of bacteria on the basis of Polymerase chain reactionamplified ribosomal DNA. Appl Environ Microbiol 59: 945-52.

\section{How to cite this article:}

Babita Mukhija and Veena Khanna. 2018. Cry Protein Profiling of Bacillus thuringiensis Isolated from Different Agro-Climate Soils of Punjab. Int.J.Curr.Microbiol.App.Sci. 7(03): 2866-2870. doi: https://doi.org/10.20546/ijcmas.2018.703.330 